\title{
Analysis of User Acceptance towards Online Transportation Technology Using UTAUT 2 Model: A Case Study in Uber, Grab and Go-Jek in Indonesia
}

\author{
Isradila $^{1}$ Indrawati $^{2}$ \\ ${ }^{1}$ International ICT Business, Faculty of Economics and Business, Telkom University \\ ${ }^{2}$ Faculty of Economics and Business, Telkom University
}

\begin{abstract}
The emergence of online transportation started in Jakarta as it constantly suffers traffic jam, causing online transportation draws attention as it helps people reaching their destination. The fee where its relatively cheaper than conventional taxi become one of the reason. However, there still many problems faced by the online transportation companies. This research objective is to analyze factors inside UTAUT 2 model that influence the consumer on using online transportation technology in Indonesia. The result shows that factors influencing the Behavioral Intention on the adoption of online transportation technology in Indonesia are Habit, Hedonic Motivation, and Performance Expectancy. Meanwhile, the factors that influence the behavior of using online transportation services are Habit, Facilitating Condition, and Behavioral Intention. The influence on Behavioral Intention is 58.07\% and the influence on Use Behavior is $46.15 \%$.
\end{abstract}

Keywords: Behavioral Intention, Use Behavior, Online Transportation, UTAUT 2

\section{Introduction}

Nowadays, people are indulged with the convenience to reach something. Things such as goods and services can be received in front of the doorstep. Even easier in obtaining information. The advance of technology has changed the way people live and socialize with each other. Due to the introduction of Internet to the public, it has been used in our daily life. There are different aspects of society that are influenced by the Internet ${ }^{[1]}$. Users in Indonesia also increase continuously. Based on survey result conducted by Association of Indonesian Internet Service Providers (Asosiasi Penyelenggara Jasa Internet Indonesia), Internet penetration in Indonesia is $51.8 \%$ (132.7 million) of the total Indonesian population $(256.2 \text { million })^{[2]}$. The difference between 2014 to 2016 is quite high. AIISP recorded that in 2014 Indonesia Internet penetration is $34.9 \%$ ( 88.1 million).

The Internet is not only changing the society but also customer behavior. Belleghem (2016) stated that mobile device perhaps the main driver on the changing of customer behavior. Because many people relying on smartphones and other smart devices. In recent years, mobile device consumption has become widespread and continues to grow significantly $^{[3]}$.

In Indonesia, users spend a significant amount of time in messaging, social and gaming ${ }^{[4]}$. Besides social media, online transportation application is also thriving. There are three main online transportation companies in Indonesia, which is Go-Jek, Grab and Uber. These three become the biggest in Indonesia as its gain substantial amount of investment to enlarge the service. Go-Jek as Indonesia's own online transportation company, raised $\$ 500$ million investment in August $2016^{[5]}$. Where Grab investing $\$ 700$ million in Indonesia as Indonesia become their biggest market $^{[6]}$. Meanwhile, Uber already raised $\$ 3.5$ billion $^{[7]}$.
The emergence of online transportation started in Jakarta as it constantly suffers traffic jam, causing online transportation draws attention as it helps people reaching their destination. The fee where its relatively cheaper than conventional taxi become one of the reason. For conventional taxi, the base rate is $\mathrm{Rp} 7,500$ with $\mathrm{Rp} 4,000$ as the rate per $\mathrm{km}$. Conventional taxis also charge $\mathrm{Rp} 700$ for the rate per minute. Minimum rate for each conventional taxi is different (even though it is almost similar) but it is Rp 40,000 and the cancellation fee is Rp 15,000. Then, for Uber, the base rate is $\mathrm{Rp} 3,000$ with $\mathrm{Rp} 2,000$ as the rate per $\mathrm{km}$. Uber charges $\mathrm{Rp} 300$ for the rate per minute, the minimum rate is $\mathrm{Rp}$ 3,000 and cancellation fee is $\mathrm{Rp} 30,000$. Meanwhile, for Grab, the base rate is $\operatorname{Rp} 2,500$ with $\mathrm{Rp} 3,500$ as the rate per $\mathrm{km}$. Minimum rate is $\mathrm{Rp} 10,000$ and there is no rate per minute and cancellation fee for Grab. As for Go-Car, there is no base rate, rate per minute and cancellation fee. However, Go-Car charges $\mathrm{Rp} \mathrm{10,000} \mathrm{for} \mathrm{minimum} \mathrm{rate} \mathrm{and} \mathrm{Rp} 3,500$ for the rate per $\mathrm{km}^{[8]}$.

When consumers shift from conventional taxis to online transportation services, conventional taxi drivers get the consequences which lead to poor business performance. Express Group reported their revenue decreasing $28.95 \%$ from 2015 to 2016 where their profit falling 873\%. Similar to Express Group, Blue Bird Group also shows that their revenue decreasing $9.67 \%$ from 2015 to 2016 where their profit falling $42.3 \%$. Although Blue Bird Group declining is not as much as Express Group, this condition shows how transportation service industry is getting competitive ${ }^{[9]}$.

The author took these phenomena as a study to understand online transportation technology adoption in Indonesia. As it is fascinating to observe how a startup company can expand their service in short amount of time. Besides, there is no study that published related with this matter, yet. Moreover, this study uses UTAUT 2 model from Venkatesh et al., (2012). As it is based on previous eight technology 


\section{International Journal of Science and Research (IJSR) \\ ISSN (Online): 2319-7064 \\ Index Copernicus Value (2015): 78.96 | Impact Factor (2015): 6.391}

acceptance theories. UTAUT 2 is the technology acceptance theory that works in a consumer context while the previous UTAUT model is applicable in organizational contexts ${ }^{[10]}$. Therefore, the objective of this study is to analyze if the UTAUT 2 model can be used to predict the behavioral intention and use behavior of customers in Indonesia toward online transportation in Indonesia.

\section{Unified Theory of Acceptance and Use of Technology (UTAUT) 2}

UTAUT model was first developed by Venkatesh et al. (2003) aims to explain technology acceptance. It has four main determinants of Behavioral Intention which are Performance Expectancy, Effort Expectancy, Social Influence and Facilitating Conditions and, four moderating variables that affect the determinants: gender, age, experience and voluntariness of use.

In 2012, Venkatesh, Thong, and $\mathrm{Xu}$ extend the unified theory of acceptance and use of technology (UTAUT) to study acceptance and use of technology in a consumer context. Meanwhile, the previous UTAUT is related to the use of technology in the organizational context ${ }^{[10]}$.UTAUT extensions have three broad types which are to observe in new contexts, such as new technologies, new user populations, and new cultural setting, then the addition of new constructs in order to expand the scope of the endogenous theoretical mechanisms and lastly the inclusion of exogenous predictors of UTAUT variables ${ }^{[10]}$. A new construct that has been added such as Hedonic Motivation, Price Value, and Habit. Venkatesh et al. also modified one moderating variable, Voluntariness of Use.

As this study wants to predict behavioral intention and use behavior in a consumer context, thus UTAUT 2 is applied as a conceptual model in this research. UTAUT 2 that has been developed by Venkatesh et al. (2012) is modified to suit the context of the research, which online transportation service. A proposed model by Indrawai et al. (2015) is based on UTAUT 2 model with an additional construct, which is Mobile Friendliness. Their research on modification of UTAUT 2 model for measuring instant messenger can be applied in a mobile application (i.e. online transportation application) as well. Indrawati et al. (2015) proposed this model as "it is important to increase the usage of the application especially in Indonesia which is considered still low compared to Malaysia." ${ }^{[11]}$.

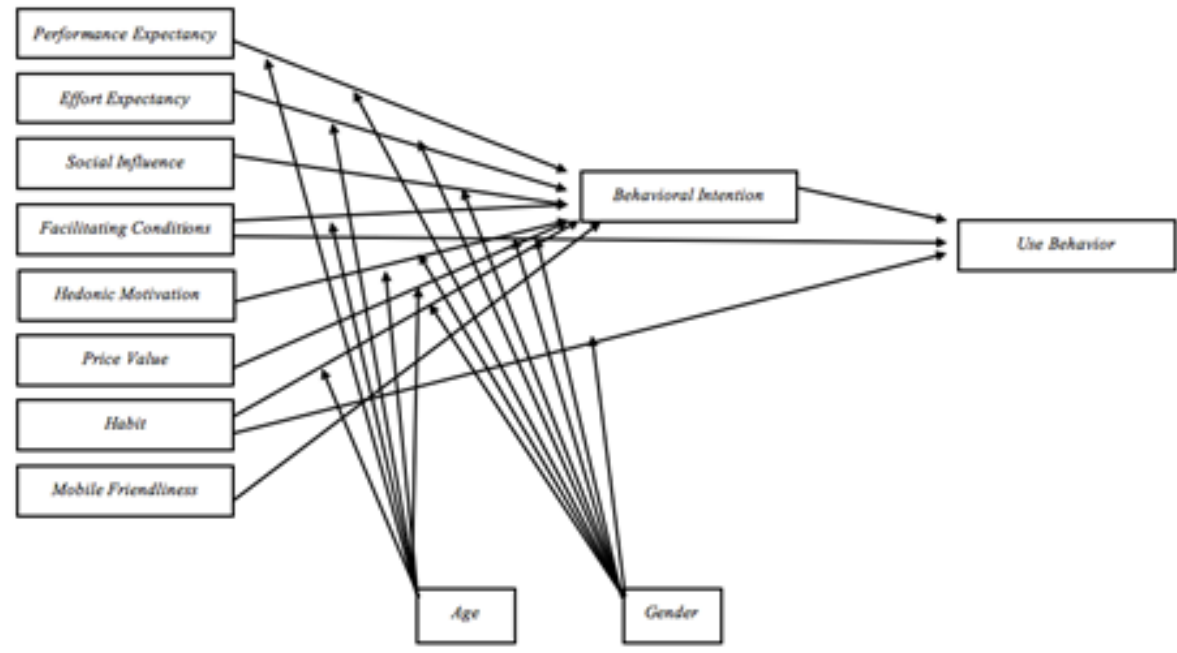

Figure 1: Conceptual Model adopted from UTAUT2 (Venkatesh et al., 2012)

This study defines each variable based on Venkatesh et al., (2003 and 2012) as follows: performance expectancy describes a user's belief that use of online transportation technology provides many benefits on their daily life. Effort expectancy on this research explains that online transportation user didn't find any difficulties in using the technology. Social influence is defined as the extent to which members of social networks such as friends and family, influence one another's behavior on using online transportation technology. This study defines Facilitating Condition variable as the degree to which an individual believes that factors such as availability of devices, knowledge, or people from social group exist to support the use of online transportation technology. This study defines Hedonic Motivation as the degree of fun or pleasure derived from using online transportation technology. Habit is defined as the extent to which people tend to use online transportation technology automatically because of learning. Mobile Friendliness is the condition of the application that can be operated even when the connection is slow and it only needs little data storage. This study defines Use Behavior as the frequency of the users in using online transportation technology.

The hypotheses in this research are summarized in Table 1 below: 
International Journal of Science and Research (IJSR)

ISSN (Online): 2319-7064

Index Copernicus Value (2015): 78.96 | Impact Factor (2015): 6.391

Table 1: Hypothesis of the Research

\begin{tabular}{|c|c|}
\hline No & Research Hypothesis \\
\hline 1. & Performance Expectancy has positive and significant influence towards Behavioral Intention \\
\hline 1a. & Influence of Performance Expectancy towards Behavioral Intention is moderated by Age \\
\hline 1b. & Influence of Performance Expectancy towards Behavioral Intention is moderated by Gender \\
\hline 2. & Effort Expectancy has positive and significant influence towards Behavioral Intention \\
\hline 2a. & Influence of Effort Expectancy towards Behavioral Intention is moderated by Age \\
\hline $2 \mathrm{~b}$. & Influence of Effort Expectancy towards Behavioral Intention is moderated by Gender \\
\hline 3. & Social Influence has positive and significant influence towards Behavioral Intention \\
\hline 3a. & Influence of Social Influence towards Behavioral Intention is moderated by Gender \\
\hline 4. & Facilitating Conditions have positive and significant influence towards Behavioral Intention \\
\hline $4 \mathrm{a}$. & Influence of Facilitating Conditions toward Behavioral Intention is moderated by Age \\
\hline 4b. & Influence of Facilitating Conditions toward Behavioral Intention is moderated by Gender \\
\hline 5. & Hedonic Motivation has positive and significant influence towards Behavioral Intention \\
\hline $5 \mathrm{a}$. & Influence of Hedonic Motivation towards Behavioral Intention is moderated by Age \\
\hline 5b. & Influence of Hedonic Motivation towards Behavioral Intention is moderated by Gender \\
\hline 6. & Price Value has positive and significant influence towards Behavioral Intention \\
\hline 6a. & Influence of Price Value towards Behavioral Intention is moderated by Age \\
\hline 6b. & Influence of Price Value towards Behavioral Intention is moderated by Gender \\
\hline 7. & Habit has positive and significant influence towards Behavioral Intention \\
\hline $7 \mathrm{a}$. & Influence of Habit towards Behavioral Intention is moderated by Age \\
\hline $7 \mathrm{~b}$. & Influence of Habit towards Behavioral Intention is moderated by Gender \\
\hline 8. & Mobile Friendliness has positive and significant influence towards Behavioral Intention \\
\hline $8 \mathrm{a}$. & Influence of Mobile Friendliness towards Behavioral Intention is moderated by Gender \\
\hline 9. & Facilitating Conditions have positive and significant influence towards Use Behavior \\
\hline 9a. & Influence of Facilitating Conditions toward Use Behavior is moderated by Age \\
\hline $9 \mathrm{~b}$. & Influence of Facilitating Conditions toward Use Behavior is moderated by Gender \\
\hline 10. & Habit has positive and significant influence towards Use Behavior \\
\hline 10a. & Influence of Habit towards Use Behavior is moderated by Gender \\
\hline 11. & Behavioral Intention has positive and significant impact towards Use Behavior \\
\hline
\end{tabular}

\section{Research Method and Result}

To test the hypothesis, this study collects data from 400 respondents, through a survey by using questionnaire distributed to respondents. To analyze the data that collected, the researcher used a Smart PLS 2.0 software. In PLS, there are 2 different testing model that is conducted, which is the outer and inner model. Outer model is used to test the indicators with their own latent variable or in other words to measure how far the indicators able to describe the latent variable. Indicators are tested with convergent validity, discriminant validity and also Average Variance Extracted (AVE), and composite reliability. The other test that will be conducted is the inner model. Inner model is used to test the influence of one latent variable to the other latent variable. The test itself conducted by looking at the percentage of variance that explained, which is $R^{2}$ for dependent latent variable modeled is influenced by an independent latent variable. This stability estimation is tested by using $t$-statistics test, through bootstrapping procedure.

In PLS, the correctness of the proposed model can be measured by using path coefficient (PC) and R-square $\left(R^{2}\right)$. The path coefficients should have t-values of at least 1.28 at $90 \%$ significance level and 1.65 at $95 \%$ significant level. Table 2 shows the path coefficients and t-values of the model as a result of bootstrapping:

Table 2: Path Coefficient and t-Value

\begin{tabular}{|c|c|c|c|c|c|}
\hline Variable Relationship & Path Coefficient & t-Value & Variable Relationship & Path Coefficient & t-Value \\
\hline EE -> BI & -0.0505 & 0.4884 & PV > BI & 0.0703 & 0.7487 \\
\hline FC -> BI & 0.0434 & 0.3440 & SI -> BI & 0.0739 & 0.8893 \\
\hline H -> BI & 0.4212 & $3.3855^{*}$ & BI -> UB & 0.1936 & $1.5648^{* *}$ \\
\hline HM -> BI & 0.2005 & $1.6469^{* *}$ & FC -> UB & 0.2564 & $2.1998^{*}$ \\
\hline MF -> BI & 0.0433 & 0.5239 & H > UB & 0.3317 & $2.9033^{*}$ \\
\hline PE -> BI & 0.1597 & $1.3886^{* *}$ & & & \\
\hline
\end{tabular}

Note: $*$ at $95 \%$ significance level $* *$ at $90 \%$ significance level

Some of the variables have a positive and significant influence on Behavioral Intention such as Habit, Hedonic Motivation, and Performance Expectancy. This study has two R-square with the value of 0.5807 for the latent construct of Behavioral Intention and 0.4615 for the latent construct of Use Behavior, these two values indicate that the model has substantial power to predict the behavioral intention and usage behavior of people on the adoption online travel services.

In order to measure the influence of age and gender as moderating variables, this study uses a group comparison approach. This study performed the following steps to test

\section{Volume 6 Issue 7, July 2017} www.ijsr.net 


\section{International Journal of Science and Research (IJSR) \\ ISSN (Online): 2319-7064}

Index Copernicus Value (2015): 78.96 | Impact Factor (2015): 6.391

the differences between sub-group: 1) Split the sample according to the group (e.g., men and women; young and adult, low and high income). 2) Calculate each group in a separate model in Smart PLS. 3) Compare the differences of the paths using the method proposed by Chin ${ }^{[12]}$.

$$
t=\frac{\text { Path }_{\text {sample1 }}-\text { Path }_{\text {sample2 }}}{\sqrt{\text { s.e. } \cdot_{\text {sample } 1}^{2}+\text { s.e. } \text { sample2 }_{\text {sample }}^{2}}}
$$

The comparison is shown on the table $3 \& 4$. Below:

Table 3: T-Values of compares path young and adult

\begin{tabular}{|c|c|c|}
\hline $\begin{array}{c}\text { Compared } \\
\text { Paths }\end{array}$ & $\begin{array}{c}\text { t-Values of } \\
\text { Compared Paths }\end{array}$ & Conclusions \\
\hline H - BI & -0.6633 & There is no significant difference \\
\hline HM - BI & $2.4189^{*}$ & There is a significant difference \\
\hline PE - BI & -1.1708 & There is no significant difference \\
\hline FC - UB & 0.1857 & There is no significant difference \\
\hline H - UB & -0.5935 & There is no significant difference \\
\hline
\end{tabular}

Table 4: T-Values of compares path male and female

\begin{tabular}{|c|c|c|}
\hline $\begin{array}{c}\text { Compared } \\
\text { Paths }\end{array}$ & $\begin{array}{c}\text { t-Values of } \\
\text { Compared Paths }\end{array}$ & Conclusions \\
\hline H - BI & 0.6659 & There is no significant difference \\
\hline HM - BI & -0.7687 & There is no significant difference \\
\hline PE - BI & -0.4602 & There is no significant difference \\
\hline
\end{tabular}

\section{Conclusion and Discussion}

According to UTAUT 2 model, factors that influencing the Behavioral Intention on the adoption of online transportation services in Indonesia are Habit, Hedonic Motivation, Performance Expectancy. While factors that influencing Use Behavior are Habit, Facilitating Condition, and Behavioral Intention. The influence on Behavioral Intention is $58.07 \%$, while the influence on Use Behavior is $46.15 \%$. The Age moderating variable is moderating the influence of Hedonic Motivation. While Gender is not moderating any influence.

All the factors inside UTAUT 2 model are known that able to predict and influence the behavioral intention and use behavior on using technology, so in the development of online transportation services in Indonesia, need to consider those factors. From the result of this research, service providers are expected to be able to consider which factors from UTAUT 2 model, that need to be their priority, so they can correlate it on develop their business strategy.

\section{References}

[1] Rajani, M., K., and Chandio, M., S. (2004). Use of Internet and Its Effects on Our Society National Conference on Emerging Technologies. 157.

[2] PENETRASI \& PERILAKU PENGGUNA INTERNET INDONESIA. (2016). Retrieved Jan 2017, from apjii.or.id Internet Users in Indonesia

[3] Belleghem, S., V. (2016). How the Digital World is Shaping the Modern Consumer. Strategic Direction, 32(5), 1-2.

[4] Waesche, N. (2015). Indonesia's Love Affair with Messaging - Top 15 Apps. [online]. https://blog.gfk.com/2015/12/indonesias-love-affairwith-messaging-top-15-apps/ [January 3, 2017]
[5] Tegos, M., (2017). Brief: Go-Jek reportedly about to raise $\$ 1 b$ to fight off Uber and Grab in Indonesia. [online]. https://www.techinasia.com/go-jek-fundingreport-1b. [May 29, 2017]

[6] Vasagar, J., (2017). Ride-hailing app Grab to invest $\$ 700 m$ in Indonesia.[online]. www.ft.com/content/f01be4f8-e8ef-11e6-893c082c54a7f539. [May 29, 2017]

[7] Kosoff, M. (2016). Why is Uber Raising So Much Money? [online]. http://www.vanityfair.com/news/2016/06/why-is-uberraising-so-much-money [January 3, 2017]

[8] Adhi. (2016). KomparasiTarifTaksi Online Vs TaksiKonvensional. [online]. http://www.money.id/digital/komparasi-tarif-taksionline-vs-taksi-konvensional- 160323p.html [January 23, 2017]

[9] Aria, P. (2016). Tambah Armada, Uber GandengTaksi Express. [online]. http://katadata.co.id/berita/2016/12/19/tambah-armadauber-gandeng-taksi-express[January 5, 2017]

[10] Venkatesh, V., Thong, J. Y., \& Xu, X. (2012). Consumer Acceptance and Use of Information Technology: Extendding the Unified Theory of Acceptance and Use of Technology, 36(1), 157-178.

[11] Indrawati, Raman, M., Ariyanti, M. and Chew, K., W. (2015). A Proposed Model for Measuring Instant Messenger Applications Adoption Among Indonesians and Malaysians. International Conference on Technology Management, Business and Entrepreneurship.

[12] Chin, W. W. (2000). Frequently Asked Questions Partial Least Squares \& PLS-Graph. http://discnt.cba.uh.edu/chin/plsfac/plsfac.htm.

\section{Volume 6 Issue 7, July 2017 www.ijsr.net}

